In recognition of his discovery among family papers of the lost correspondence of Descartes with Huygens Buxton was awarded the Légion d'Honneur.

In due course, Buxton was elected to a fellowship on the foundation of his College, of which later he became bursar. The business ability which he showed revealed capacities of which the University also readily took advantage. In carrying out these duties, his success was at least in some measure due to a geniality which had won him the affection of his pupils, his colleagues and his contemporaries.

\section{Mr. Howard Carter}

IT is with regret that we have to record the death, on March 2, of Mr. Howard Carter, the painter and archæologist, whose name will always be remembered as the discoverer of the tomb of Tutankhamen.

Born at Swaffham in Norfolk in 1873, Carter was the youngest son of Samuel Carter, the animal painter. Owing to delicate health he never went to a public school but as a lad worked at painting with his father. At the age of eighteen years he first went to Egypt as a draughtsman on the staff of the Archæological Survey of Egypt, then being carried out under the auspices of the Egypt Exploration Fund. His earliest line-drawings were published in the present writer's "EI Bersheh I" (1893), and many of his water-colour drawings of the animals and birds figured in the tombs at Beni Hasan, and executed in 1892, are reproduced in colour in "Beni Hasan IV" (1900). In 1892 he was for three months assistant to Mr. (now Sir) Flinders Petrie in the excavations that were then being carried out at El Amarna, Lord Amherst of Hackney defraying all C'arter's expenses.

In the autumn of 1893 Carter was again in Egypt, this time as draughtsman to M. Naville at Deir el Bahari, and with Naville he worked for six years; the greater number of the plates of the six folio volumes of Naville's "Deir el Bahari" (1895-1903) were printed from Carter's drawings. In 1900 he was appointed inspector-general of the monuments of Upper Egypt under the Egyptian Government and during the four years that he held this post he did much restoration work in the temples of Western Thebes, Edfu, and Kom Ombo. In the Valley of the Tombs of the Kings he installed electric light in six of the more important tombs, and the electric light installation in the Temple at Abu Simbel in Nubia was also carried out by him.

In January 1902, at Carter's instigation, Theodore M. Davis, an American, undertook to finance a systematic exploration of the Valley of the Tombs of the Kings at Thebes for the benefit of the Services des Antiquités, and this work was entrusted to Carter. Among the discoveries he then made were the royal tombs of Tuthmôsis IV (Carter-Newberry, "The Tomb of Thoutmôsis IV", 1904), and Hatshepsût (Naville-Carter, "The Tomb of Hatshopsitu", 1906). When Lord Carnarvon began excavating at Thebes in 1908, Carter, at the express desire of Sir
Gaston Maspero, then director-general of the Service des Antiquités, was appointed to supervise the excavations and record all 'finds'. After five years work, there appeared the handsome volume "Five Years Explorations at Thebes" by Carnarvon, Carter and others. In 1914 Carter by a lucky chance found the long-sought-for tomb of Amenhotep I ( $J$. Egyptian Archoology, 3, 147 ; 1916), and soon afterwards he located a tomb of Princess Hatshepsût, which the Arabs had recently found and plundered (ibid., 4, $107 ; 1917$ ).

At the conclusion of the Great War, Carter persuaded Carnarvon to let him once again explore in the Valley of the Tombs of the Kings, and in 1922 he was rewarded by the discovery of the tomb of Tutankhamen with its extraordinary wealth of jewels and tomb furniture. Carter at once realized that only with the help of a large staff of expert workers could he attempt to clear the tomb of all the treasures it contained. Fortunately, this problem was quickly solved through the generosity of the Egyptian Expedition of the Metropolitan Museum of Art, New York. In answer to Carter's appeal, Mr. A. M. Lythgoe, the curator of the Egyptian Department of the Museum, placed at his disposal Mr. A. C. Mace, one of the associate curators, Mr. Harry Burton, their expert photographic recorder, and Messrs. Hall and Hauser, draughtsmen to their expedition. At the same time, Mr. Lucas, director of the Chemical Department of the Egyptian Government, offered his aid, and all were soon at work. During the years that followed other workers were enrolled, including Dr. Alexander Scott and Dr. Derry. Altogether it took ten years to record the contents of the tomb and to preserve the objects so that they might be safely packed for transport to the National Museum at Cairo. Carter and his staff published three popular volumes on the tomb and its contents between 1923 and 1933; but much remains still to be published and this it is hoped will soon be done by the Cairo Museum authorities. Only a few weeks ago Prof. Georg Stoindorff published, in the Annales des Services des Antiquités de l'Égypte, 38, 641-667), a full account of the paintings on the walls of the tom's.

Percy E. Newberry.

\section{Mr. E. R. Bolton}

Edward Richards Bolton, who died on February 10 , w as born in Dublin in 1878, and was the only son of J. A. Bolton of Blackrock, Co. Dublin, of long Irish ancestry. He was at school at Bedford (Elstow) and studied chemistry at King's College, London, and in Fresenius's laboratory, Wiesbaden. On his return to England he was engaged for a short period in heavy chemical industry in Newcastle and in 1902 became chemist to the East India Products Oil Mills, Hammersmith, later Loders and Nucoline, Ltd. At these mills, Bolton carried out the first caustic refining of coco-nut oil in Great Britain. He became a director of the firm, having in the meantime started in analytical and consulting practice in Hammersmith. 
Bolton quickly established a commanding position as analyst, consultant and technical adviser in the oil and fat and many food industries. In 1920, Tochnical Research Works Ltd. was founded, with premises in Milner Street, Sloane Square, Bolton being. managing director, and transferring his analytical and consulting practice to the same address. 1920 is notable, too, in that it is the date of Bolton's patent for the continuous hydrogenation of unsaturated oils, fats and the like.

Much original work came from Bolton's fertile mind and clever hands: it was published mostly in the Analyst, from the year 1910, his last two papers (with K. A. Williams) being in 1938, both dealing with whale oil: his aptitude in devising apparatus and instruments is exemplified in the Bolton and Williams colorimeter. He also served on a number of research committees, particularly on analytical methods; at the time of his death he had just begun work with the "S.P.A." Sub-Committee on the determination of unpolymerisable matter in oils. Outstanding among his publications, there appoared in 1911 his book "Fatty Foods" (Bolton and Revis) a second edition of which, with the title "Oils, Fats and Fatty Foods" (Bolton) came in 1928.

Bolton was a well-known member of many societies; particular mention should be made of his services to the Society of Public Analysts and Other Analytical Chemists, of which he was honorary secretary from 1915 until 1925 and president during 1926-1927. For a period he was honorary treasurer of the Federal Council for Chemistry, and later was a member of the British Council for Chemistry of the Royal Society, a member of the delegacy of King's College, London, and a Royal Institution Visitor.

Seemingly in the full vigour of life, Bolton died, suddenly, after an illness from which he was thought to be recovering, leaving a widow and a host of friends to lament his loss. He was a remarkable and muchloved man, held in universal regard and affection alike by his staff, his colleagues and a wide circle of professional and business friends. His death is a serious loss to the profession of chemistry; yet throughout his life he did much to minimize this loss, for generosity in giving to others the fruits of his own gifted mind and of his wide experience was a notable characteristic of his ever-generous nature.

E. HrNks.

\section{Prof. C. C. Okell}

Prof. Charles Cyril Okell, who died on February 9, was educated at Douglas Grammar School, St. John's College, Cambridge, and St. Bartholomow's Hospital, and distinguished himself as a student. He became medically qualified during the Great War and served in the R.A.M.C. as lieutenant and captain in France, Palestine and Egypt, and was awarded the Military Cross when a regimental medical officer. Soon after the War he became bacteriologist to the Wellcome Physiological Research Laboratories at Beckenham, and loft that institution to become professor of bacteriology at
University College Hospital Medical School, London. He was for some time assistant editor of the Journal of Pathology and Bacteriology and at the time of his death was editor of the Journal of Hygiene.

Okell's active scientific life began at Beckenham. Ho was soon engaged in what has since become one of the main labours of the laboratory - the investigation of the problem of human immunization against diphtheria. He collaborated with Glenny in an important paper on the meaning of the Ramor flocculation test for diphtheria antitoxin. This was followed by a large volume of work on the problem of immunization against scarlet fever and a number of papers on the hæmolytic streptococcus and its toxin. $\mathrm{He}$ was also concerned in a comprehensive examina. tion of the sugar reactions of the diphtheria bacillus and the development of an intracutaneous test for the virulence of diphtheria bacilli which made the routine testing of virulence much cheaper and more practical. $\mathrm{He}$ also published papers on the standardization of dysentery antitoxin, scarlet fover antitoxin and tuberculin, and was among the first to realize the importance of the application of statistical methods to biological assay.

Okell was part author of a paper which was perhaps the first to establish with statistical rigour the fact that 'B.C.G.' had some immunizing power against virulent tubercle bacilli. One of his last efforts at Beckenham was his attempt with Hindle to establish the possibility of vaccination against yellow fever, an exciting and dangerous piece of work, which he approached in the same spirit of detachment which characterized all his efforts.

On his appointment to the chair at University College Hospital Medical School, Okell delivered the Milroy Lectures in 1932, in which he summarized the fruit of his labours for many years on the hæmolytic streptococcus. $\mathrm{He}$ also mado the discovery that simple operations such as tooth extractions are followed in a large number of cases by the appearance of streptococci in the blood of the patients, a most important observation which he would have followed up but for the rapid onset of the ailment which led to his retirement to Cambridge.

All Okell's work was done in collaboration with others. He loved the company of his fellows both in work and in leisure. He did not like working alone, and always discussed what he was doing with all and sundry. He was a great conversationalist, and was always worth listening to, not only when talking of his special subject, but also when ranging at large over literature, art and ethics. In none of the work in which he collaborated was his contribution the least important factor and he was generally the moving spirit. His work was never far removed from practical application. Interested though he was in fundamental problems, it could be seen that the motive of his work was primarily the benefit of the sick, particularly in the prevontion of disease.

Okell was universally popular, and the gradual restriction of the field of his labours by his illness was a grief to all of his friends. He leaves a memory of care for others and single-hearted devotion to medicine which will endure.
J. W. Trevan. 